\title{
Club Management: Practicum: A Case Study in Evidence that Practicums are "Better" than Internships
}

\author{
Joe Bogdan \\ Columbia College Chicago \\ This paper was presented at the 2018 International Summit of the \\ Music \& Entertainment Industry Educators Association \\ March 22-24, 2018
}

https://doi.org/10.25101/18.18

\section{Abstract}

Experiential learning, as such, is not new. It has its roots with early Greek philosophers like Socrates, Aristotle, and Plato. Research argues that it builds knowledge base, skills, confidence, and career-related relationships better than classroom learning. Two of the most popular types of experiential learning in higher education are internship and practicum. Yet virtually all the scholarship focuses on internship over practicum. This suggests that far more professors and institutions use internship than use practicum, a fact that was confirmed by research on the topic. The Business and Entrepreneurship Department of Columbia College Chicago has a robust music-industry-related offering of practicum courses, including Club Management: Practicum, in which students have run a local, privately-owned nightclub for a series of six shows each semester for the past six years. By providing Club Management: Practicum as a case study of a robust and mature practicum course, the author: 1) argues that practicums are "better" than internships, 2) urges the professoriate to devote more of both its course development and its scholarly research to practicum courses, and 3) provides professors teaching or desiring to teach practicum courses with advice and tools stemming from experience, as well as sample documents, for use in their courses.

Keywords: internship, practicum, practica, live events, experiential learning, music business pedagogy
"For the things we have to learn before we can do them, we learn by doing them." Aristotle

\section{Introduction}

Experiential learning has its roots with early Greek philosophers, but it was not until the 1970s that it emerged as a recognized field. It is distinct from rote or didactic learning and can generally be described as learning through doing. An experiential learner proceeds through multiple phases, learning while doing. Ultimately, utilizing feedback amassed, the student understands the subject matter at hand. Many other authors acknowledge that there is a significant divide between theoretical knowledge and application in a career.

While experiential learning experiences vary, in both name and substance, two well-known forms of experiential learning are internship and practicum. Internships take on the characteristics of a real job in the workplace setting, whereas practicums are simulated to emulate the work environment. Despite the availability to the academy of both these types of experiential learning offerings, nearly all the scholarship pertains to internship, rather than practicum. From the scholarship, then, much can be learned about internships; conversely, very little can be learned about practicums. This suggests that a far greater number of professors and institutions use internship than use practicum, a fact that was confirmed by research on the topic.

The Business and Entrepreneurship Department of Columbia College Chicago has a robust offering of more than a dozen practicum courses, including not only the somewhat common ones in which students, for example, run a record label. Columbia College also offers practicums in which students work on projects related to digital distribution and promotion, talent management, talent booking, and museum and gallery management. In the live events space, in particular, Columbia College Chicago effectively offers more than half-a-dozen practicums, focused on specific 
genres of live entertainment (e.g., music, dance, comedy). In one such practicum, Club Management: Practicum, students have run a local, privately-owned nightclub for a series of six shows each semester for the past six years.

Using Club Management: Practicum as a case study of a robust and mature practicum course, one can conclude that practicums are "better" learning experiences for students than internships. Further, one can make the case that the professoriate should devote more of both their course development and their scholarly research to practicum courses so that this valuable method of experiential learning might further mature pedagogically. Finally, this paper provides professors teaching or desiring to teach practicum courses with advice and tools stemming from experience, as well as sample documents for use in their courses.

\section{Methodology}

I used three primary approaches in research and preparation of this paper. First, I developed, launched, and taught (for a number of years) the Columbia College Chicago course Club Management: Practicum. Over the course of the years, I collected information, tracked empirical data, developed quantitative course materials, and developed qualitative best practices. This body of information was not only the inspiration for, but also the cornerstone of, this paper.

Second, I researched the scholarship on experiential learning, generally, and internships and practicums, specifically. Indeed, the initial conception of this paper was merely as a case study intended to inform the professoriate of a course that we have developed at Columbia College Chicago that we believe is unique and impactful. Over the course of the formal research, however, it became apparent that the scholarship on experiential learning in higher education is focused almost exclusively on internships rather than practicums, suggesting both that far more academicians use internships than use practicums and that the internship is believed to be the "better" method of experiential learning. Over the course of the formal research, it also became apparent that the scholarship on internships highlights numerous potential benefits of, potential pitfalls of, and obstacles to administration of, internships.

Our experience with Club Management indicates that using practicums rather than internships allows the academy to avail itself of nearly all the benefits of internships, while simultaneously avoiding nearly all of the potential pitfalls and obstacles to administration. Stated differently, over the course of the formal research, it became apparent that perhaps practicum, in fact, is a "better" method of experiential learning than internship. As such, this paper morphed from a mere case study into a case study with a purpose, namely a case study in evidence that practicums are "better" than internships.
Third, I researched the landscape of course offerings at institutions other than Columbia College, attempted to telephone-interview all of the professors who have developed and/or teach those courses (as well as some professors whose course titles made them look like they fit the bill, but ultimately did not), and also attempted to set up site visits to those institutions and professors, along with the live events that they produce and promote and the students who produce and promote them. I believe I have identified the entire landscape of such offerings, and in spring semester 2017, telephone-interviewed everyone who was willing and able to participate in my research, including faculty members from Bay State College, Carnegie Mellon University, Michigan State University, Point Park University, University of Colorado Denver, University of South Carolina, and University of Miami. In general, the interviews were open-ended conversations of about one hour each, catalyzed by a set of standard questions I asked every interviewee, as follows:

- Tell me about your background as a professional and academic

- Tell me about the live events practicum that it appears, from the course title visible online, you teach, including:

- Whether it is a practicum or otherwise has an academic component

- Its age/maturity (i.e., how long have you been doing it?)

- Its faculty (i.e., who teaches it, if not you?)

- Its resources (i.e., what resources do you get from your institution and/or third-parties?)

- Its location, particularly whether on-campus or off-campus

- Its programming philosophy (e.g., number of events/shows per semester, all music/all theatre/all comedy, etc., cover charge and alcohol policies)

- The materials that you have created or otherwise use to teach it

- Tell me about the students who typically take the course, including:

- The roles they typically fill

- The course's capacity, both currently and historically

- How they evaluate it (i.e., positively or negatively)

A fourth step of the research will be the site visits to the institutions, professors, live events, and students referenced in the preceding paragraph, which are yet to come. As such, the further research that I will conduct in those site visits will likely be fodder for a follow-up article. 


\section{Experiential Learning}

Experiential learning, as such, is not new. It has its roots with early Greek philosophers like Socrates, Aristotle, and Plato but it was not until the 1970s that experiential education emerged as a recognized field, and not until 1977 that the Association for Experiential Education (AEE) was established (Hammerman, Hammerman, and Hammerman 2001). "Learning in which the learner is directly in touch with the realities being studied...is contrasted with the learner who only reads about, hears about, talks about, or writes about these realities but never comes into contact with them as part of the learning process" (Keeton and Tate 1978).

Experiential learning is distinct from rote or didactic learning, in which the learner plays a comparatively passive role (Beard 2010). Experiential learning has been defined as "learning through reflection on doing" (Felicia 2011). Jennifer A. Moon has elaborated on this to argue that experiential learning is effective because it involves: 1) a "reflective learning" phase, 2) a phase of learning resulting from the actions inherent to experiential learning, and 3) a final phase of learning from feedback (Moon 2004). Steinaker and Bell dissected even further and described experiential learning as a five-step process: 1) exposure, 2) participation, 3) identification, 4) internalization, and 5) dissemination (Steinaker and Bell 1979)

Providing an example under Moon's model, learning to ride a bicycle without training wheels first involves a reflective learning phase where one identifies a goal of riding without the assistance of training wheels and observes others doing so. In that phase, one might identify success as riding without incident and include contemplation of the components of the bicycle, and the laws of gravity and motion in relation to balance and pedaling, respectively. The student's initial experience of actually riding might be wobbly at first, and reflection upon that phenomenon would comprise the second phase of the experiential learning process. Upon completion of reflection and analysis, the student would undertake the third phase of the experiential learning process, namely, utilizing the feedback amassed, getting back on the bicycle, and successfully riding without the aid of training wheels.

John Dewey believed that all learning is active and that, therefore, schooling is unnecessarily long and restrictive. He believed that students should be involved in real-life tasks and challenges. For example, math could be learned via working with proportions in cooking or calculating how long it would take to travel from one place to another by mule (Neil 2005). Many other authors, at the very least, acknowledge that there is a great divide between what is learned on a theoretical basis and what constitutes knowl- edge in the workplace (Crook et al. 1984; Fletcher 1988; Hall et al. 1995).

Where the arts and entertainment are concerned, according to Strasser and McLaughlin, "Experiential education is considered an integral component of music industry education today... [because it is] an opportunity for students to increase their knowledge of the music industry from a practical perspective" (Strasser and McLaughlin 2007). For example, students wanting to learn how to mix live sound might prepare by studying microphones, microphone placement techniques, and the different parts of a mixing board. However, until the students arrive at the venue, connect the microphones, and run the mixing board while the band is playing, they will not genuinely know the variables they may encounter during the performance. "You can spend hours and hours learning how to use microphones [and] compression...it means nothing until you are in with someone working on a genuine product, that's what it is all about" (Davis, Parker, and Thompson 2014).

Below is a partial list of fundamental building blocks of experiential learning in an academic setting, chosen from a larger list because of their relevance to the study of, and preparation for, a career in arts and entertainment.

- Building Skills. Experiential learning promotes both student exploration and collaboration with teachers and peers to solve problems and increase involvement in the learning process, which helps with student motivation (Discovery 2018). Even more so, certain skills take on an entirely different dynamic in an interpersonal interaction, as opposed to the reading of a book or even the viewing of a video. It is easy to envision how many disciplines lend themselves to experiential learning. For example, public speaking, which can be taught either in the classroom or experientially, such as a Toastmasters group. In the classroom, students might view online videos that provide a good overview of the topic. In the experiential environment of Toastmasters, however, students would typically find an opportunity to study techniques in an interactive fashion and then, most importantly, practice in a relatively safe environment before any "real" public appearance.

- Building Confidence. Anna Alanko (quoted in Baker 2013) believes that one particular type of experiential learning - an internship - is a valuable learning experience. "Perhaps the student will find the industry so interesting that an internship will cement your career decision. Perhaps you'll find the industry so boring that the internship will lead you to a change your career plans. But it's better to learn that lesson during a one-semester internship than as a 
full-time employee." Healy and Mourton assert that internships aid in the development of personal skills not necessarily related to the subject matter of the experiential learning, including confidence (Healy and Mourton 1987).

- Building Relationships. One of the most important things people need to succeed in, yet do not formally learn in school, is networking. Networking comprises meeting new people in a professional context, forging a connection, building those relationships over time, and providing value to each other. This skill is essential because eighty-five percent of a person's success is due to "human engineering"one's personality, communication ability, negotiation skills, and emotional intelligence (all of which are involved in what is colloquially known as networking). A mere fifteen percent is because of technical knowledge (Bradford 2016). One component of experiential learning is exposure to opportunities to meet people, often in companies and other environments within their desired career track. According to Matt Youngquist, president of Career Horizons (quoted in Kaufman 2011), "Most jobs aren't posted or advertised publicly. At least 70 percent, if not 80 percent, of jobs are not published, yet most people are spending 70 or 80 percent of their time surfing the net versus getting out there, talking to employers, taking some chances [and] realizing that the vast majority of hiring is friends and acquaintances hiring other trusted friends and acquaintances."

- Building Knowledge Base. It would be difficult to contend that being in the right environment with access to the primary tools of a chosen profession will not accelerate personal growth and development. Davis (2014) contends that knowledge in the recording industry must become second nature to the student so that he or she does not have to think about all the equipment and can become more transparent and get to the real reason why a band comes to a studio, which is to record an album.

We see, then, that experiential learning is valuable.

\section{Internship and Practicum - Two Popular Types of Experiential Learning}

Experiential learning experiences vary, and different terminology is used within different industries. For this paper, we will look at two common forms of experiential learning, namely, internship and practicum.

Internships take on the characteristics of a real job in the workplace setting where students work with on-site professionals who manage their workload and oversee their performance much as an administrator in an actual employment setting would. Additionally, students enrolled in a practicum course also sometimes spend time with faculty during the internship for the purpose of evaluating their progress and performance ("What is the Difference..." 2018).

As compared to internships, practicums are "simulated work environments" that attempt to emulate work-based practices (Oultram 2012). They allow a student to observe and document how to perform job responsibilities and also afford an opportunity to perform tasks under supervision by faculty and/or staff. Additionally, students enrolled in a practicum course also sometimes concurrently enroll in one or more other courses that outline the expectations and requirements of the practicum ("What is the Difference..." 2018).

Despite the availability to the academy of both these types of experiential learning offerings, nearly all of the scholarship pertains to internship, rather than practicum. From the scholarship, then, much can be learned about internships.

\section{Internships}

The purpose of an internship is to provide a planned transition from the classroom to the job, and internships are a natural bridge between college and the work world (Farinelli and Mann 1994). In the highly competitive job market today, merely having a diploma may not have the same effect on the ability to procure employment in the way it may have in generations past.

According to The National Association of Colleges and Employers (NACE), “An internship is a form of experiential learning that integrates knowledge and theory learned in the classroom with practical application and skills development in a professional setting. Internships give students the opportunity to gain valuable applied experience and make connections in professional fields they are considering for career paths; and give employers the opportunity to guide and evaluate talent" (Position 2011).

One might conclude, from the sheer overwhelming weight of scholarship pertaining to the internship rather than the practicum, that internship is the "better" method of experiential learning. Indeed, it seems the professoriate believes this. For example, it has been stated that "...[i]t is a commonly held belief in...music business education that internships are not just important...they are essential (Rolston and Herrera 2000). Channell and Anderson add that "...while learning about the music industry it is crucial to have an internship that brings to life theory and practice" (Channell and Anderson 2010).

Despite the foregoing, it is widely acknowledged that there are not only benefits but also significant detriments, to internships. Perhaps the most extensive discussions of such benefits and detriments were by Maertz, Stoeberl, and Marks (2014) and Christensen and Shaomian (2016). 
Maertz et al. put forth a list of twenty potential benefits of internships to students and schools but also a list of eleven potential pitfalls. Christensen and Shaomian narrowed to the music industry and put forth their own list of ten common obstacles to music industry internship administration. Those lists, combined in table form, are provided in Appendix A (potential benefits per Maertz et al.) and Appendix B (potential pitfalls per Maertz et al., and obstacles per Christensen and Shaomian).

\section{Practicums}

As mentioned above, there is a dearth of scholarship on practicum courses and experience. Notwithstanding that, let us focus for a moment on practicums, particularly those offered by the Business and Entrepreneurship Department ("BUSE") in the School of Fine and Performing Arts at Columbia College Chicago.

\section{Non-Live Events Practicum Courses in BUSE at Columbia College Chicago}

The Business and Entrepreneurship Department ("BUSE") of Columbia College Chicago provides its students with a robust offering of practicum courses, allowing students the opportunity for such diverse experiences as running a record label, a talent agency, and an art gallery. See Appendix $\mathrm{C}$ for a complete list of Columbia College Chicago's BUSE practicum courses.

\section{Live Events Practicum Courses in BUSE at Columbia College Chicago}

Even where only Columbia College's Live and Performing Arts Management major is concerned, the practicum course offerings are multiple. In name, only two courses are offered-Events Management: Practicum and Club Management: Practicum, the latter of which is the subject of this paper. However, that two-course offering belies the variety of the live events practicum offering, because each of those two courses is offered in multiple "flavors". While Club Management: Practicum is discussed at length below, in Events Management: Practicum, students plan and execute a variety of live events, with six different flavors of the course, including 1) sections geared to each of the theatre, music, and dance genres, 2) a section geared to the college-wide fall celebration "Holipalooza", 3) a section geared to the college-wide spring celebration "Manifest", and 4) a "wild card" section of sorts, the genre of which changes in relation to the off-campus venue that is secured for a given semester.

\section{A Case Study: Club Management: Practicum}

Aside from the six flavors of the Events Management course mentioned above, BUSE at Columbia College Chicago also offers Club Management: Practicum, a course that has matured over a period of seven years into a state- ment in support of the practicum over the internship as a preferred method of experiential music industry education.

\section{History}

In 2011, BUSE (then named the Arts, Entertainment and Media Management, or AEMM, Department) set a goal of re-launching Club Management as a true practicum. Prior to that time, the course had been essentially of the non-practicum variety, with reading and traditional assignments, but with an actual live event incorporated into the end of the semester. The course was re-launched as a true practicum on the Columbia College Chicago campus in a venue room known as "Haus at the Quincy Wong Center," which is essentially a seating area for study, social exchange, and student breaks, which had previously been outfitted with a stage and modest lights and sound.

In the re-launched Club Management, the sole focus is a practicum experience that simulates the rapid-fire experience of running a nightclub. While the first three weeks of each semester are dedicated to preparation and planning, the first show is in week four. For the rest of the semester, the class sessions rotate production meeting (week five), show (week six), production meeting (week seven), show (week eight), and so on. This results in the "rapid-fire" practicum immersion, with a schedule of at least six shows. If the students in a given semester are performing particularly well, an additional show is added in week thirteen or fifteen, bringing the total number of shows to seven. The course is designed this way to simulate as closely as possible, in a course setting, the life of a real club owner or manager, whose venue may be open 365 days a year.

Due to the expected intensity of the experience, as well as the safety and other risks inherent in live events settings, an initial decision was made to set the course capacity at twelve students. The course is not currently required as a part of any major but, rather, serves as an elective to undergraduate students College-wide, as well as those in the Columbia College Chicago Master of Arts Management program. Historically, the course has filled to capacity.

While the course was initially re-launched in 2012 on campus at "Haus at the Quincy Wong Center", after five semesters, it was moved into the community, via a collaboration with Reggies on State. Reggies is one of Chicago's best-known rock clubs, and its talent buyer is a Columbia College Chicago part-time faculty member. Students in Club Management now produce and present all of their shows at Reggies. This provides not only additional authenticity to the experience as compared to the original on-campus venue (which was subject to both a "no alcohol" policy and a "no cover charge" policy) but also four separate rooms in which shows may be booked: 1) Reggies' on-site record store, in which in-store performances can be booked, 2) 
Reggies' rooftop beer garden, where small, typically acoustic acts can perform, 3) Reggies Music Joint, essentially a restaurant with a stage in a room with a 111 capacity, and 4) Reggies Rock Club, a 300-capacity rock club with full, professional sound and lights sufficient for nationally-touring acts. At Reggies, the same basic course format is followed as was followed in the on-campus version of the course, except the multiple rooms at Reggies afford the opportunity not only for different genres of performance to be considered by the student talent buyers (see below) but also for multiple rooms (i.e., multiple shows) to be booked on a single night, which, in turn, affords the opportunity to increase course capacity (it is currently set at twenty).

Now, ten semesters in, the course counts among its successes scores of shows by hundreds of performers, thousands of satisfied patrons, and dozens of educated and experienced alumni. The reader may view BUSE's three-minute, promotional video for the course online at https://www. youtube.com/watch? $=\mathrm{k} 1 \mathrm{KKM} 4 \mathrm{a} 2 \mathrm{VTw}$. That video also should be the topline result in response to a search on YouTube for "Club Management Practicum".

\section{Binder of Materials}

Upon re-launch of Club Management in 2012, it was very much a "seat-of-the-pants" experience for students and faculty alike. The on-campus venue had been secured, and the syllabus had been prepared with the "shows are every other week, starting in week four" philosophy. However, there was no other infrastructure, and the students were more or less charged with figuring it out. Perhaps this point is best illustrated by the manner in which the instructor opened the course in fall of 2012:

"I've got bad news, good news, and real bad news. The bad news is that your grandmother died. The good news is that she left you this club. The real bad news is that, now that you own it, three weeks from tonight, there's going to be a show on that stage, and it's all on you. Good luck."

The instructor then walked out for effect, only to return a few minutes later to help the students begin the work in earnest.

Over time, however, the processes and procedures of Club Management began to take shape. Notably, a binder of materials was created, and that binder of materials serves as a living and breathing "bible" for the course. While the course binder contains virtually everything required for the course, its meat is a collection of templates and pre-existing resources for each of the major roles in the course- - executive management, talent buying, marketing, and production. See Appendix D for the table of contents from the most recent iteration of the binder.

\section{Student Experience}

As mentioned above, the major roles in the course are executive management, talent buying, marketing, and production. However, and as those involved with nightclubs would attest, there is much more to be done to bring nightclub shows to successful completion. In addition to the major roles, students work front of house sound, work stage monitor sound, check IDs, collect patron information at the door, curate and manage sponsorships and vendors, and emcee the shows from the Reggies' stages. Students do not fill nightclub roles that have a higher inherent risk such as bartending and bouncing - for those roles, regular Reggies' staff is on-hand. See Appendix E for a detailed list of student roles and what each role entails.

It is worth noting that since the student experience is now in a real nightclub, with all that such a venue has to offer, for better or for worse, students are asked on the first day of class to sign a Code of Conduct. In that document, students acknowledge, among other things, that using, selling, providing, possessing, and/or being under the influence of drugs or alcohol while conducting Club Management business at Reggies would be actionable to the same extent as would such behavior be if on campus.

\section{Experimentation}

As Club Management has evolved, it has provided a generous platform for experimentation and collaboration. For example, in collaboration with the Comedy Studies Program offered by Columbia College Chicago, a "comedy-only" section of Club Management was launched. That section, which to date has run only on-campus at the original Club Management venue, Haus at the Quincy Wong Center, may eventually move off-campus to a local comedy club, in emulation of what the original Club Management section has done.

Other Club Management collaborations and experimentations have included:

- Producing and presenting record release parties and South by Southwest sendoff parties in collaboration with the Columbia College Chicago BUSE AEMMP Record Label: Practicum course (in which students run the country's oldest student-run record label).

- Inviting students from the Columbia College Chicago BUSE Talent Agency: Practicum course (in which students run a talent agency) to pitch their artists for bookings on a Club Management stage.

- Producing and presenting, on a Club Management stage, the final examination performance poetry slam of the Columbia College Chicago Creative Writing Department's Creative Writing/Performance Poetry course. 
- Working with the Columbia College Chicago Television Department's Directing and Production: Live Broadcast and Directed Study: Television (Truck) to have the College's media production truck and students on-site at Reggies to record and broadcast Club Management shows.

Those collaborations have often been the most meaningful parts of those other courses, while enriching the Club Management students' experiences as well.

\section{Lessons Learned}

Over the years of running Club Management: Practicum, many lessons have been learned. Those lessons can serve as guidance to other educators who may be embarking upon or who are contemplating embarking upon a live events practicum of their own.

- Do use a written manual or binder. It makes a lot of sense to use a pre-existing manual or binder of materials for a live events practicum course, because leaving students entirely to their own design to reinvent the wheel for each task would create too great a set of inefficiencies for both the students and the instructor (particularly where grading is concerned). On the other hand, the binder that exists for Club Management: Practicum may at times be too comprehensive. Its sheer size can intimidate students at the outset of the semester. For example, when the Club Management binder was smaller, in the formative semesters of the course, the first-class admonition to students that they should skim through it to familiarize themselves was typically heeded; whereas that is generally no longer the case, because it is "too big".

- Do use rubrics.

One of the early student criticisms of Club Management: Practicum was that students did not have a clear idea of how they were graded. This, anecdotal$\mathrm{ly}$, is a common issue with practicum courses and a reason why many professors "give all 'A's" in some practicum courses. For that reason, a set of grading rubrics was developed for Club Management, and those rubrics are provided to students at the semester's outset (in the binder) so that they can see the manner in which they have the ability to score well (or poorly). See Appendix F for sample grading rubric from Club Management (this one, for a show).

- Do be a coach and leader without usurping students' responsibilities.

Another common trap for instructors of practicum courses is expecting too much from students (i.e., that the students will perform as well as profession- als in the field) and/or improperly reacting to student shortcomings. Be careful to allow the students to succeed or fail on their own merits. In Club Management: Practicum, it has been the case that the most valuable student lessons - the ones they still talk about years later-have been the failures. Some highlights from our years at Columbia College Chicago include the night the cash box walked off, the time the students booked a thrash metal band to play a mall food court, and the time the most expensive act the course ever booked had a fatal equipment failure just ten minutes into the set.

- Do collaborate and experiment. Collaboration and experimentation have been key to the success and student value of Club Management: Practicum. Our experience has been that collaboration and experimentation at all levels has made the course more genuine, inserting real outcomes for the students. While this is especially true in our collaboration with Reggies, it is also true for our other collaborations and experimentations.

- Don't allow cliques to form.

This lesson was learned in Club Management:

Practicum in its first semester, when the original vision was to divide the students into teams and leave those teams in place for the entire semester. The catalyst for that decision was a desire for efficiency and the thought that good, old-fashioned competition would elevate all students' performance. Unfortunately, cliques were the outcome, and ultimately each clique cared only about its responsibilities and shows (e.g., students from Clique A did not have any interest in marketing, or even merely attending, a show that was the ultimate responsibility of Clique B).

- Don't grow section size too large.

Practicum courses often have fewer students than do classroom courses. This only makes sense. However, in today's world, with constant budgetary pressure to increase section size across the board, practicum sizes have crept up. One thing that must be kept in mind for a live events practicum is that live events inherently involve greater risk than do practicum courses in other subject matter areas taught in an arts and entertainment curriculum. In the real world, all too common are the occurrences of stage collapse, fire, stampede, and violence. By contrast, it is difficult to imagine personal injury or property damage occurring in the normal course of operation of most practicum courses. At Columbia College Chicago, while we are thankful that we have not had a personal injury or property damage mishap in any live 
events practicum, it would seem far less likely to have such an event occur in our record label, our talent agency, or our music publishing practicums than it would to have such an event occur in a nightclub at which there is live entertainment on stage and several hundred patrons in attendance. Keeping course capacity in check is one way to reduce this risk.

- Don't expect perfection.

This "don't" point is the analog of the "do" point above regarding being a coach and leader without usurping students' responsibilities. Again, it is important to not expect too much from students and to take care to allow the students to succeed or fail on their own merits.

\section{- Don't expect ease.}

Virtually all readers of this paper will know the amount of time it typically requires to prepare, teach, and grade an average classroom course. Many readers of this paper will also know the amount of time it typically requires to prepare, teach, and grade an average practicum course and that it is typically significantly higher than for a classroom course. For a live events practicum course, however, there is an exponential multiplier. In Club Management: Practicum, the instructor's role consumes an average of two hours per day, every day (weekends included) when classes are in session (and assuming the students are doing everything that they should be doing... which they often are not). On show days, load-in at the club is typically 5:00 p.m. and post-show strike is typically 1:00 a.m., making for an eight-hour "class period". Since there are six or seven shows each semester in Club Management, that means forty-eight to fifty-six contact hours accumulate in just six to seven of fifteen class sessions. Adding in the twenty-four to twenty-seven contact hours for the remaining seven or eight class sessions yields a total of seventy-two to eighty contact hours for the course, as opposed to the forty-five contact hours required for a classroom course. In short, the amount of time required to teach a course like Club Management is immense and not for the time-strapped.

\section{Why Club Management: Practicum is Evidence that Practicums are "Better" than Internships}

Strasser argues that job-seeking graduates, "...must be able to address the complexities and ambiguities of decision making in a business environment" (Strasser 2006).

The scholarship around internships provides long lists of potential advantages, potential problems, and obstacles to administration thereof (see Appendices A and B). For an analysis of the potential advantages, potential pitfalls, and obstacles of internships as compared to practicums, see Appendix G (potential benefits) and Appendix H (potential pitfalls and obstacles). That comparison is evidence that, except for those potential advantages as to which no data is available, practicum provides $87.5 \%$ of the potential advantages, but only $19 \%$ of the potential problems and obstacles, that internships present. Stated another way, by using practicum rather than internship, professors can avail themselves of $87.5 \%$ of the advantages while avoiding $81 \%$ of the problems!

\section{Conclusion}

Using Club Management: Practicum as a case study of a robust and mature practicum course, one can conclude that practicums are "better" learning experiences for students than are internships. Empirically, practicum provides nearly all the potential advantages of internships while presenting only a small portion of the potential problems and obstacles.

Notwithstanding the empirical evidence on the value of the practicum, it has been neglected in the scholarship, and presumably on campus as well. The professoriate should devote more of both its course development and its scholarly research to practicum courses so that this valuable method of experiential learning might further mature pedagogically.

Any professor teaching or desiring to teach practicum courses is urged to not only consider the advice, tools, and sample documents provided in this paper, but also to look further for additional tools that can be leveraged to more easily develop, launch, and teach their own courses.

\section{Acknowledgments}

The author would like to acknowledge and thank Columbia College Chicago Graduate Research Assistants Emily Evans and Beth Zupec for their invaluable assistance with some of the heavy-lifting of research into both the scholarship on internships and practicums as well as the breadth of live-events-related course offerings across the United States.

The author would also like to express gratitude to the professors at other institutions who made time for an interview conducted in research for this paper. Further thanks, in advance, to those of them who have also committed to shepherding site visits to the live events their students produce and present.

Finally, the author would like to thank BUSE Chair Emeritus Philippe Ravanas, BUSE Chair Mary Filice, former SFPA Dean Eliza Nichols, former SFPA Dean John Green, and SFPA Dean Onye Ozuszu of Columbia College Chicago, for embracing the vision of, and providing the necessary resources for, not only the Business \& Entrepreneurship practicum offering, generally, but Club Management: Practicum, specifically. 


\section{Appendix A. Potential Benefits of Internships}

Source: Maertz et al. 2014.

\begin{tabular}{l} 
Potential Benefits of Internships \\
\hline Student Benefit - Understanding of how classroom concepts apply practically \\
\hline Student Benefit - Improved on-the-job knowledge and skills \\
\hline Student Benefit - Improved knowledge of industry and possible career options \\
\hline Student Benefit - Improved work habits \\
\hline Student Benefit - Increased personal and social efficacy \\
\hline $\begin{array}{l}\text { Student Benefit - Reduced shock and increased comfort and efficacy for post-graduation work } \\
\text { transition }\end{array}$ \\
\hline $\begin{array}{l}\text { Student Benefit - Development and crystallization of one's vocational self-concept and work/ } \\
\text { career values }\end{array}$ \\
\hline Student Benefit - Marketable practical job experience \\
\hline Student Benefit - Higher starting salaries and faster advancement than non-interns \\
\hline Student Benefit - More job offers and earlier job offers than non-interns \\
\hline Student Benefit - Opportunity to evaluate company as a potential employer \\
\hline Student Benefit - Possible direct offer of employment \\
\hline $\begin{array}{l}\text { School Benefit - Experiential, practical, or "bridging" education to supplement and complement } \\
\text { classroom pedagogy }\end{array}$ \\
\hline School Benefit - Demonstrated success in preparing students for jobs \\
\hline $\begin{array}{l}\text { School Benefit - Improved marketing to/attraction of students based on ability to offer relevant } \\
\text { internships }\end{array}$ \\
\hline School Benefit - Improved job placement numbers and related alumni and parent loyalty \\
\hline School Benefit - Improved school rankings caused by placement and visibility effects \\
\hline $\begin{array}{l}\text { School Benefit - Improved/increased relationships with employer organizations and the } \\
\text { community }\end{array}$ \\
\hline $\begin{array}{l}\text { School Benefit - When for course credit, tuition payments for hours with low/no added faculty } \\
\text { labor cost }\end{array}$ \\
\hline $\begin{array}{l}\text { School Benefit - Satisfied graduates more receptive and open to various university/school } \\
\text { "requests" after graduation }\end{array}$ \\
\hline
\end{tabular}




\section{Potential Pitfalls and Obstacles of Internships}

Unclear or misrepresented employer standards on internship goals, expectations, or duties can lead to frustration and disillusionment.

Many employers do not make it clear that they do not expect to offer interns later job opportunities.

Unchallenging, routine, or irrelevant work tasks

Inadequate training, monitoring, and feedback by employer

Inadequate faculty and/or school involvement

Transportation, time, and other lost opportunity costs

If for course credit, the intern must typically pay tuition for intern hours

Increased ongoing administrative oversight required compared to traditional classroom

coursework

Faculty internship supervisors give time that could be spent on other production/outputs (e.g., research)

Staff internship program administration and faculty involvement is time-consuming, often underappreciated by the institution and low-paid, which can lead to issues of low motivation and morale.

Some threat of legal liability is possible, related to negligence in setting up and/or monitoring the internship.

Failure between faculty and worksite supervisor to embrace a team-teaching mentality

Failure between faculty and worksite supervisor to recognize differences in relationship dynamics

Faculty failure to determine the viability of the experiential learning opportunity

Worksite supervisor failure to work with the student

Worksite supervisor inexperience with students

Worksite supervisor teaching from instinct rather than pedagogy

Worksite supervisor impatience

Student failure to connect academic knowledge to the experiential learning

Failure to enter into a "learning agreement"

Student failure to recognize that the experiential learning experience is an academic course

Appendix C. List of Columbia College Chicago Business and Entrepreneurship Department Practicum Courses

AEMMP Record Label - Rock

AEMMP Record Label - Hip Hop

AEMMP Music Publishing

AEMMP Digital Distribution and Promotion Agency

Digital Business Development

Sponsorship

Branded Entertainment

Creative Agency

Artist Management

Curatorial

Gallery Management 


\section{Appendix D. Club Management: Practicum Student Binder Table of Contents}

1. General
a. Syllabus
b. Tips for Success
c. Rules for Guest Speaker Visits
d. Columbia College Chicago Release and Waiver
e. Club Management Code of Conduct
f. REGGIES What's Included

2. Student Roles for Shows

3. Schedule of Show Dates and Teams

4. Master Calendar
a. Show Preparation Schedules
i. Shows $1 / 2$
ii. Shows $3 / 4$
iii. Shows $5 / 6$
b. Master Calendar

5. Executive Management
i. Vendor Agreement
ii. Sponsor Letter
a. Legal:
b. Sample Email from GM to Team re: actual budget vs. planned budget
c. Expense Payment and Reimbursement Guidelines
d. Columbia College Chicago Tax Exempt Document
e. Executive Management Report

6. Talent Buying
a. Legal
i. Venue Contract (for artists who will be paid)
ii. Venue Contract - Promotional (for artists who will NOT be paid)
b. Club Management Promo

7. Marketing
a. Poster/Handbill Guidelines
b. Reggies Poster Template
c. Instructions for Poster Approval and Distribution in Dorm Buildings
d. Columbia College Chicago B\&E Department Online Communications Guide
e. Social Media User Names and Passwords
f. Show Marketing Plan Template
g. Potential Sponsors

8. Production
a. Show Report
b. Columbia College Chicago Workroom Information Sheet
c. Sample Production Schedule - Professional
d. Sample Production Schedule - Class
e. Sample Stage Plots and Input Lists

9. Budget
a. Budget Dates and Deliverables
b. Sample Budget (last semester)
c. Budget (this semester)

10. Grading
a. Grading Tracking Spreadsheet
b. Grading Rubric - Show
c. Grading Rubric - Written Budget
d. Grading Rubric - Budget Dress Rehearsal
e. Grading Rubric - Budget Presentation

11. Show 1

12. Show 2

13. Show 3

14. Show 4

15. Show 5

16. Show 6 


\section{Appendix E. Club Management: Practicum Student Roles}

- General Management (1 each room)

- Develop objectives with your team

- Define what success means (specific, objective evaluation criteria)

- Follow-up on team members to meet deadlines and accomplish goals

- Manage budget and request purchases

- Determine how revenue can be generated from your events

- Find and contract with vendors

- Find and contract with sponsors

- Talent Buying (2 each room)

- Develop programming philosophy

- Identify performers, ascertain availability/repertoire/set durations, and get contracts negotiated/signed

- Provide Marketing with all information required to publicize the event

- Apprise Operations of any special needs/setup requirements of the performer(s)

- Production (1 each room)

- Initiate, manage, and execute technical needs with the venue

- Devise and implement floor plan and setup for audience and performer(s)

- Schedule, including load-in, set up, soundcheck, performance, and load-out times

- Coordinate with security

- Prepare and complete Event Critique Report
- Sound

- Rock Club (2 - FOH and monitors) - shadow Reggies sound techs

- Music Joint (1, aged 21+ only) - shadow Reggies sound tech

- Record Breakers (1) - run sound

- Roof (1) - run sound

- Door 1 (each room) - Check IDs and keep total headcount

- Door 2 (each room)

- Verify guest list patrons

- Keep ticket counts

- Gather emails, phone numbers, etc. from patrons

- Marketing (3, covering both rooms)

- Develop plan to promote event, including marketing/public relations/media plan

- Determine whether Press Release or other media is appropriate

- Sponsorship (1 each room) - Columbia College and outside sponsors + promoting Club Management to student patrons.

- Emcee (1 each room) - announce acts, promote class, etc.

\section{Appendix F. Sample Club Management: Practicum Grading Rubric}

\section{Name of Show:}

\section{Date of Show:}

Each of the below areas was graded, with a total of 60 points (of 1,000 for the entire course) for this assignment.

\begin{tabular}{|l|c|c|l|}
\hline \multicolumn{1}{|c}{ Grading Criteria } & $\begin{array}{c}\text { Possible } \\
\text { Points }\end{array}$ Points \\
Awarded & Comments \\
\hline $\begin{array}{l}\text { General Management: Were objectives } \\
\text { developed with the team? }\end{array}$ & 2 & & \\
\hline $\begin{array}{l}\text { General Management: Was there regular, } \\
\text { apparent follow-up by GM with the team? }\end{array}$ & 2 & & \\
\hline
\end{tabular}




\begin{tabular}{|c|c|c|c|}
\hline Grading Criteria & $\begin{array}{l}\text { Possible } \\
\text { Points }\end{array}$ & $\begin{array}{l}\text { Points } \\
\text { Awarded }\end{array}$ & Comments \\
\hline $\begin{array}{l}\text { General Management: Were supplies timely } \\
\text { ordered? }\end{array}$ & 2 & & \\
\hline $\begin{array}{l}\text { General Management: Was there a plan to } \\
\text { generate revenue, and was it executed? }\end{array}$ & 3 & & \\
\hline $\begin{array}{l}\text { General Management: Was the show delivered } \\
\text { on or under budget? }\end{array}$ & 3 & & \\
\hline $\begin{array}{l}\text { Programming: Was there a sound } \\
\text { programming philosophy? }\end{array}$ & 2 & & \\
\hline $\begin{array}{l}\text { Programming: Were the draft and final } \\
\text { contracts completed on a timely basis? }\end{array}$ & 2 & & \\
\hline $\begin{array}{l}\text { Programming: How were any artist issues } \\
\text { (e.g., arriving late, leaving early) handled? }\end{array}$ & 3 & & \\
\hline $\begin{array}{l}\text { Programming: Were "Thank You" cards } \\
\text { completed? }\end{array}$ & 3 & & \\
\hline $\begin{array}{l}\text { Production: Were the technical needs } \\
\text { initiated, managed, and executed through a } \\
\text { communicated Production Schedule? }\end{array}$ & 2 & & \\
\hline Production: Was the schedule adhered to? & 3 & & \\
\hline $\begin{array}{l}\text { Production: Was the Show Report complete } \\
\text { and accurate? }\end{array}$ & 3 & & \\
\hline $\begin{array}{l}\text { Production: Did the emcee promote multiple } \\
\text { times per the Club Management Promo } \\
\text { guidelines? }\end{array}$ & 2 & & \\
\hline $\begin{array}{l}\text { Sponsorship: Was the sponsorship effective } \\
\text { and relevant to the show? }\end{array}$ & 2 & & \\
\hline $\begin{array}{l}\text { Sponsorship: Were the draft and final sponsor } \\
\text { letters completed on a timely basis? }\end{array}$ & 2 & & \\
\hline $\begin{array}{l}\text { Sponsorship: Was an updated list of potential } \\
\text { sponsors circulated? }\end{array}$ & 2 & & \\
\hline Marketing: Was there a sound marketing plan? & 3 & & \\
\hline $\begin{array}{l}\text { Marketing: Was the flyer/poster completed } \\
\text { in adherence with Department and Reggies' } \\
\text { requirements and on a timely basis (including } \\
\text { information to Reggies for Reggies website)? }\end{array}$ & 3 & & \\
\hline Marketing: Did press release get timely sent? & 3 & & \\
\hline Marketing: Did email blast get timely sent? & 2 & & \\
\hline $\begin{array}{l}\text { Marketing: Was the social media plan } \\
\text { executed on a timely basis, with all outlets } \\
\text { covered? }\end{array}$ & 3 & & \\
\hline $\begin{array}{l}\text { Marketing: Was the marketing plan well- } \\
\text { executed (i.e., how was the crowd)? }\end{array}$ & 3 & & \\
\hline $\begin{array}{l}\text { Marketing: Was the Marketing Plan ("After") } \\
\text { complete and distributed on a timely basis? }\end{array}$ & 3 & & \\
\hline $\begin{array}{l}\text { Marketing: Was an updated list of email/cell } \\
\text { numbers circulated? }\end{array}$ & 2 & & \\
\hline TOTAL & 60 & & \\
\hline
\end{tabular}




\section{Appendix G. Potential Benefits of Internships as Compared to Practicums}

Based on Maertz et al. 2014 criteria.

\begin{tabular}{|c|c|c|}
\hline Potential Benefits of Internships & Internship & Practicum \\
\hline $\begin{array}{l}\text { Student Benefit - Understanding of how classroom concepts apply } \\
\text { practically }\end{array}$ & $X$ & $\mathrm{X}$ \\
\hline Student Benefit - Improved on-the-job knowledge and skills & $\mathrm{X}$ & $\mathrm{X}$ \\
\hline $\begin{array}{l}\text { Student Benefit - Improved knowledge of the industry and possible } \\
\text { career options }\end{array}$ & $\mathrm{X}$ & $\mathrm{X}$ \\
\hline Student Benefit - Improved work habits & $\mathrm{X}$ & $\mathrm{X}$ \\
\hline Student Benefit - Increased personal and social efficacy & $\mathrm{X}$ & $\mathrm{X}$ \\
\hline $\begin{array}{l}\text { Student Benefit - Reduced shock and increased comfort and efficacy } \\
\text { for post-graduation work transition }\end{array}$ & $\mathrm{X}$ & $\mathrm{X}$ \\
\hline $\begin{array}{l}\text { Student Benefit - Development and crystallization of one's vocational } \\
\text { self-concept and work/career values }\end{array}$ & $\mathrm{X}$ & $\mathrm{X}$ \\
\hline Student Benefit - Marketable practical job experience & $\mathrm{X}$ & $\mathrm{X}$ \\
\hline $\begin{array}{l}\text { Student Benefit - Higher starting salaries and faster advancement than } \\
\text { non-interns }\end{array}$ & $\mathrm{X}$ & No Data \\
\hline Student Benefit - More job offers and earlier job offers than non-interns & $\mathrm{x}$ & No Data \\
\hline $\begin{array}{l}\text { Student Benefit - Opportunity to evaluate company as a potential } \\
\text { employer }\end{array}$ & $x$ & \\
\hline Student Benefit - Possible direct offer of employment & $\mathrm{x}$ & \\
\hline $\begin{array}{l}\text { School Benefit - Experiential, practical or "bridging" education to } \\
\text { supplement and complement classroom pedagogy }\end{array}$ & $X$ & $\mathrm{X}$ \\
\hline School Benefit - Demonstrated success in preparing students for jobs & $\mathrm{X}$ & $\mathrm{X}$ \\
\hline $\begin{array}{l}\text { School Benefit - Improved marketing to/attraction of students based on } \\
\text { ability to offer relevant internships }\end{array}$ & $\mathrm{X}$ & $\mathrm{X}$ \\
\hline $\begin{array}{l}\text { School Benefit - Improved job placement numbers and related alumni } \\
\text { and parent loyalty }\end{array}$ & $\mathrm{X}$ & No Data \\
\hline $\begin{array}{l}\text { School Benefit - Improved school rankings caused by placement and } \\
\text { visibility effects }\end{array}$ & $\mathrm{X}$ & No Data \\
\hline $\begin{array}{l}\text { School Benefit - Improved/increased relationships with employer } \\
\text { organizations and the community }\end{array}$ & $\mathrm{X}$ & $x$ \\
\hline $\begin{array}{l}\text { School Benefit - When for course credit, tuition payments for hours } \\
\text { with low/no added faculty labor cost }\end{array}$ & $\mathrm{X}$ & $\mathrm{X}$ \\
\hline $\begin{array}{l}\text { School Benefit - Satisfied graduates more receptive and open to } \\
\text { various university/school "requests" after graduation }\end{array}$ & $\mathrm{x}$ & $\mathrm{X}$ \\
\hline
\end{tabular}


Appendix H. Potential Pitfalls and Common Obstacles to

Administration of Internships as Compared to Practicums

Based on Maertz et al. 2014 and Christensen and Shaomian 2016 criteria.

\begin{tabular}{|c|c|c|}
\hline Potential Pitfalls and Obstacles of Internships & Internship & Practicum \\
\hline $\begin{array}{l}\text { Unclear or misrepresented employer standards on internship goals, } \\
\text { expectations, or duties can lead to frustration and disillusionment }\end{array}$ & $\mathrm{X}$ & \\
\hline $\begin{array}{l}\text { Many employers do not make it clear that they do not expect to offer } \\
\text { interns later job opportunities. }\end{array}$ & $\mathrm{X}$ & \\
\hline Unchallenging, routine, or irrelevant work tasks & $\mathrm{X}$ & \\
\hline Inadequate training, monitoring, and feedback by employer & $\mathrm{X}$ & \\
\hline Inadequate faculty and/or school involvement & $\mathrm{X}$ & \\
\hline Transportation, time, and other lost opportunity costs & $\mathrm{X}$ & \\
\hline If for course credit, the intern must typically pay tuition for intern hours & $\mathrm{X}$ & $\mathrm{X}$ \\
\hline $\begin{array}{l}\text { Increased ongoing administrative oversight required compared to } \\
\text { traditional classroom coursework }\end{array}$ & $\mathrm{X}$ & $x$ \\
\hline $\begin{array}{l}\text { Faculty internship supervisors give time that could be spent on other } \\
\text { production/outputs (e.g., research) }\end{array}$ & $\mathrm{X}$ & $x$ \\
\hline $\begin{array}{l}\text { Staff internship program administration and faculty involvement is time- } \\
\text { consuming, often underappreciated by the institution and low-paid, } \\
\text { which can lead to issues of low motivation and morale. }\end{array}$ & $\mathrm{x}$ & \\
\hline $\begin{array}{l}\text { Some threat of legal liability is possible related to negligence in setting } \\
\text { up and/or monitoring the internship. }\end{array}$ & $\mathrm{X}$ & $\mathrm{X}$ \\
\hline $\begin{array}{l}\text { Failure between faculty and worksite supervisor to embrace a team- } \\
\text { teaching mentality }\end{array}$ & $\mathrm{X}$ & \\
\hline $\begin{array}{l}\text { Failure between faculty and worksite supervisor to recognize } \\
\text { differences in relationship dynamics }\end{array}$ & $\mathrm{X}$ & \\
\hline $\begin{array}{l}\text { Faculty failure to determine the viability of the experiential learning } \\
\text { opportunity }\end{array}$ & $\mathrm{X}$ & \\
\hline Worksite supervisor failure to work with the student & $\mathrm{X}$ & \\
\hline Worksite supervisor inexperience with students & $\mathrm{X}$ & \\
\hline Worksite supervisor teaching from instinct rather than pedagogy & $\mathrm{X}$ & \\
\hline Worksite supervisor impatience & $\mathrm{X}$ & \\
\hline $\begin{array}{l}\text { Student failure to connect academic knowledge to the experiential } \\
\text { learning }\end{array}$ & $\mathrm{X}$ & \\
\hline Failure to enter into a "learning agreement" & $\mathrm{X}$ & \\
\hline $\begin{array}{l}\text { Student failure to recognize that the experiential learning experience is } \\
\text { an academic course }\end{array}$ & $\mathrm{X}$ & \\
\hline
\end{tabular}




\section{References}

Baker, Thad. "Why Gaining Work Experience Is More Important Than Your Education." Brazen Life Lifestyle and Career Blog, The Huffington Post. August 14, 2013. Accessed January 05, 2018. https://www. huffingtonpost.com/brazen-life/why-gaining-work-experien b 3750261.html.

Beard, Colin. The Experiential Learning Toolkit: Blending Practice with Concepts. London: Kogan Page, 2010.

Bradford, Laurence. "8 Real World Skills College Doesn't Teach You." Under 30 Network, Forbes. May 16, 2016. Accessed April 20, 2018. https://www.forbes. com/sites/under30network/2016/05/16/8-real-worldskills-college-doesnt-teach-you/2/.

Channell, Timothy L., and Dennis M. Anderson. "Creating Virtual Internships in the Music Business." Journal of the Music and Entertainment Industry Educators Association 10, no. 1 (2010): 173-83. https://doi. org/10.25101/10.9.

Christensen, Carey, and Armen Shaomian. "Music Industry Internship Administration: Overcoming Common Administrative Obstacles That Hinder Student Learning." Journal of the Music and Entertainment Industry Educators Association 16, no. 1 (2016): 43-71. https:// doi.org/10.25101/16.2.

Crook, Robert H., Charles C. Healy, and David W. O'Shea. "The Linkage of Work Achievement to Self-esteem, Career Maturity, and College Achievement." Journal of Vocational Behavior 25, no. 1 (1984): 70-79. https:// doi.org/10.1016/0001-8791(84)90037-X.

Davis, Robert, Steven Parker, and Paul Thompson. "Preparing the Music Technology Toolbox: Addressing the Education-industry Dilemma." Journal of Music, Technology and Education 7, no. 3 (2014): 313-23. https:// doi.org/10.1386/jmte.7.3.313 1.

"Discovery Learning." WikiVividly. Accessed April 20, 2018. https://wikivividly.com/wiki/Discovery learning.

Farinelli, Jean L., and Phil Mann. "How to Get the Most Value from Your Internship Program.” Public Relations Quarterly 39, no. 3 (Fall 1994): 35-37.

Felicia, Patrick. Handbook of Research on Improving Learning and Motivation through Educational Games: Multidisciplinary Approaches. Hershey, Pennsylvania: Information Science Reference, 2011.

Fletcher, Joyce K. "The Correlation of Grade Point Average to Co-op Work Performance of Business Undergraduates." Journal of Cooperative Education 25, no. 1 (Fall 1988): 44-52. https://eric.ed.gov/?id=EJ379537. Hall, Mark, Gerald Stiles, John Kuzma, and Kevin Elliott. "A Comparison of Student and Employer Expectations with Regard to Business Internships." Marketing Edu- cation Review 5, no. 3 (1995): 41-49. https://doi.org/10 $.1080 / 10528008.1995 .11488513$.

Hammerman, Donald R., William M. Hammerman, and Elizabeth L. Hammerman. Teaching in the Outdoors, 5th ed. Danville, Ill.: Interstate Publishers, 2001.

Healy, Charles C., and Don L. Mourton. "The Relationship of Career Exploration, College Jobs, and Grade Point Average." Journal of College Student Personnel 28, no. 1 (1987): 28-34.

Kaufman, Wendy. "A Successful Job Search: It's All About Networking." NPR. February 03, 2011. Accessed January 05, 2018. https://www.npr. org/2011/02/08/133474431/a-successful-job-searchits-all-about-networking.

Keeton, Morris T., and Pamela J. Tate. Learning by Experience: What, Why, How. San Francisco: Jossey-Bass, 1978.

Maertz Jr., Carl P., Philipp A. Stoeberl, and Jill Marks. "Building Successful Internships: Lessons from the Research for Interns, Schools, and Employers." Career Development International 19, no. 1 (2014): 123-42. https://doi.org/10.1108/cdi-03-2013-0025.

Moon, Jennifer A. A Handbook of Reflective and Experiential Learning: Theory and Practice. London: RoutledgeFalmer, 2009.

Neill, James. "Introduction to John Dewey's Philosophy of Education." John Dewey: Philosophy of Education. Last updated January 26, 2005. Accessed April 20, 2018. http://www.wilderdom.com/experiential/JohnDeweyPhilosophyEducation.html.

Oultram, Teresa. "Simulated Work Environments: Facilitating Learning within Pre-apprenticeship Programs." International Journal of Organizational Analysis 20, no. 2 (2012): 238-50. https://doi. org/10.1108/19348831211227855.

"Position Statement: U.S. Internships." National Association of Colleges and Employers (NACE). 2011. Accessed January 05, 2018. https://www.naceweb.org/ about-us/advocacy/position-statements/position-statement-us-internships/.

Quotes.net, STANDS4 LLC, 2018. "Aristotle Quotes." Quotes.net. Accessed April 20, 2018. https://www. quotes.net/quote/1866.

Rolston, Clyde Philip, and David Herrera. "The Critical Role of University-Sponsored Internships for Entry into the Professional Music Business: A Report of a National Survey." The Journal of Arts Management, Law, and Society 30, no. 2 (2000): 102-12. https://doi. org/10.1080/10632920009601289.

Steinaker, Norman W., and Robert M. Bell. The Experiential Taxonomy: A New Approach to Teaching and Learning. New York: Academic Press, 1979. 
Strasser, Richard. "Simulation and Role Playing in Music Industry Education: An Assessment of the Effectiveness of an In-Class Simulation on Music Marketing Students' Perceptions and Learning Outcomes." Journal of the Music and Entertainment Industry Educators Association 6, no. 1 (2006): 77-91. http:// www.meiea.org/resources/Journal/html_ver/Vol06 No01/2006 Vol 6 No 1 A4.htm.

Strasser, Richard, and Kate McLaughlin. "An Investigation of the Impact of Music Industry Cooperative Education on Student Academic Performance as Measured by Grade Point Average." Journal of the Music and Entertainment Industry Educators Association 7, no. 1 (2007). https://doi.org/10.25101/7.8.

"What is the Difference Between a Practicum and an Internship?" Best Counseling Degrees. Accessed April 19, 2018. https://www.bestcounselingdegrees.net/faq/ what-is-the-difference-between-a-practicum-and-aninternship/.

Joe Bogdan is an Associate Professor and Coordinator of the Live \& Performing Arts Management Major in the Business and Entrepreneurship Department of Columbia College Chicago. He began his career as an intellectual property attorney in private practice focusing on the leveraged exploitation of entertainment content through new media platforms. He is the past Sr. Vice President of Business and Legal Affairs for World Wrestling Entertainment, where he held primary responsibility for running the day-to-day operation of the Business Affairs of the company. $\mathrm{He}$ is also a partner in the law firm of Culhane Meadows, where he practices media, entertainment, and intellectual property law.

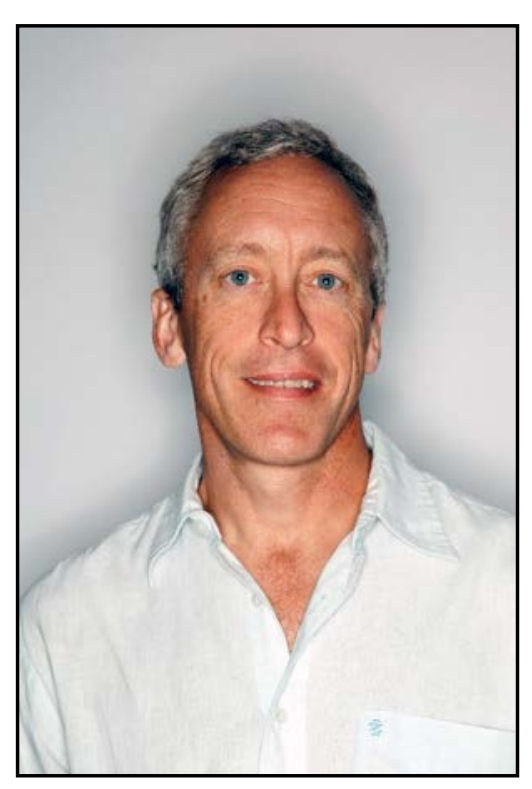




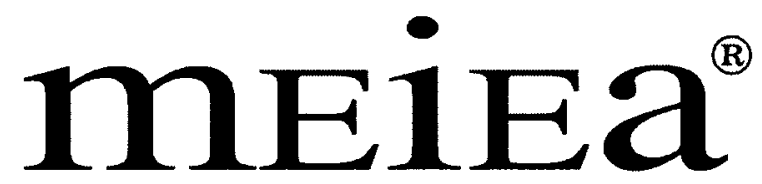

MUSIC \& ENTERTAINMENT INDUSTRY

EDUCATORS ASSOCIATION

\section{PROCEEDINGS OF THE \\ 2018 INTERNATIONAL SUMMIT}

OF THE

\section{MUSIC \& ENTERTAINMENT INDUSTRY EDUCATORS \\ ASSOCIATION}
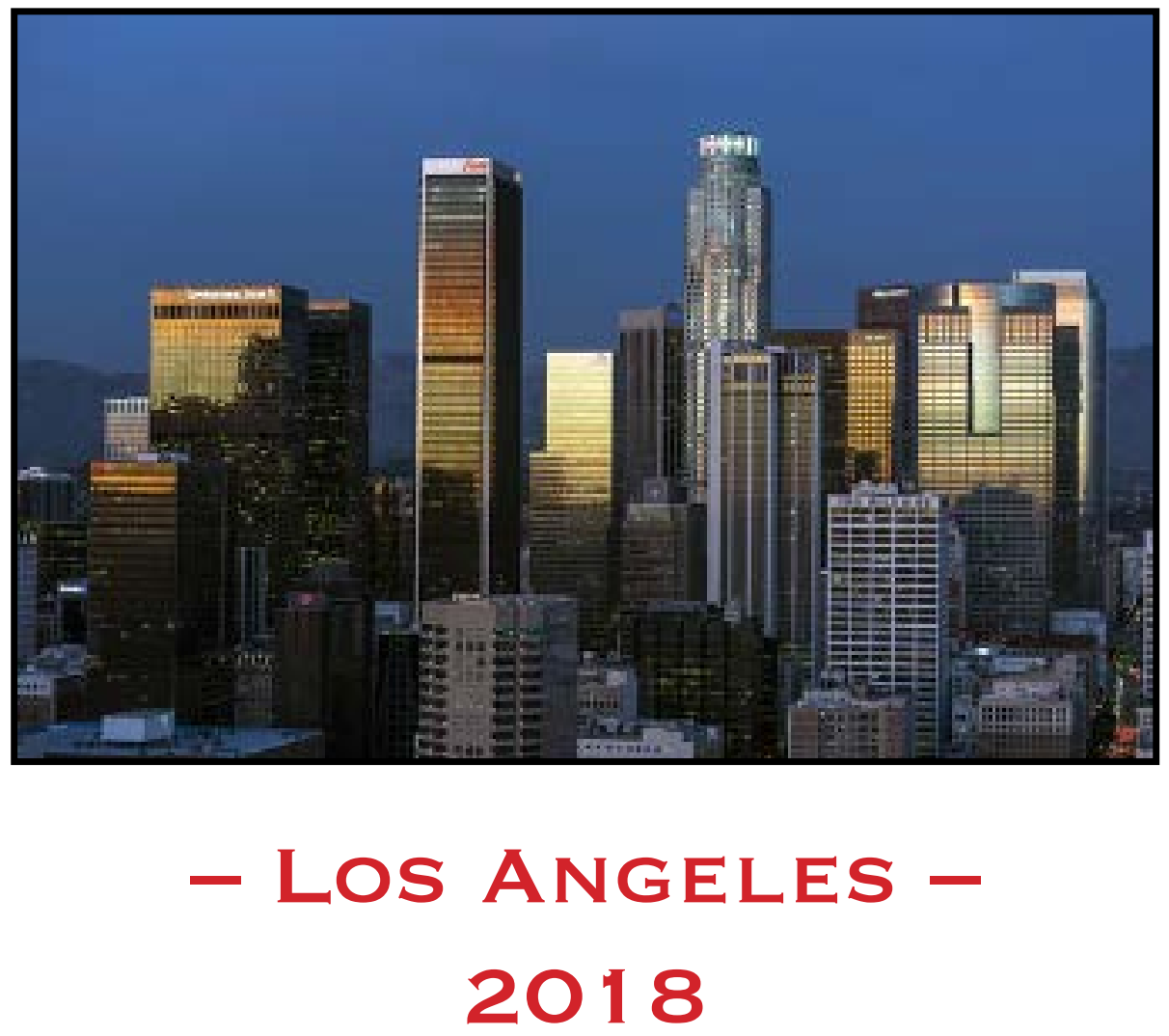

March 22 - 24, $2018 \cdot$ Embassy Suites by Hilton - Los Angeles/Glendale 